\title{
Health effects of diesel exhaust emissions
}

\author{
A. Sydbom*, A. Blomberg ${ }^{\#}$, S. Parnia ${ }^{\#, \uparrow}$, N. Stenfors ${ }^{\#}$, T. Sandström\# , S-E. Dahlén*
}

\begin{abstract}
Health effects of diesel exhaust emissions. A. Sydbom, A. Blomberg, S. Parnia, N. Stenfors, T. Sandström, S-E. Dahlén. (C) ERS Journals Ltd 2001.

ABSTRACT: Epidemiological studies have demonstrated an association between different levels of air pollution and various health outcomes including mortality, exacerbation of asthma, chronic bronchitis, respiratory tract infections, ischaemic heart disease and stroke. Of the motor vehicle generated air pollutants, diesel exhaust particles account for a highly significant percentage of the particles emitted in many towns and cities. This review is therefore focused on the health effects of diesel exhaust, and especially the particular matter components.

Acute effects of diesel exhaust exposure include irritation of the nose and eyes, lung function changes, respiratory changes, headache, fatigue and nausea. Chronic exposures are associated with cough, sputum production and lung function decrements. In addition to symptoms, exposure studies in healthy humans have documented a number of profound inflammatory changes in the airways, notably, before changes in pulmonary function can be detected. It is likely that such effects may be even more detrimental in asthmatics and other subjects with compromised pulmonary function.

There are also observations supporting the hypothesis that diesel exhaust is one important factor contributing to the allergy pandemic. For example, in many experimental systems, diesel exhaust particles can be shown to act as adjuvants to allergen and hence increase the sensitization response.

Much of the research on adverse effects of diesel exhaust, both in vivo and in vitro, has however been conducted in animals. Questions remain concerning the relevance of exposure levels and whether findings in such models can be extrapolated into humans. It is therefore imperative to further assess acute and chronic effects of diesel exhaust in mechanistic studies with careful consideration of exposure levels. Whenever possible and ethically justified, studies should be carried out in humans.

Eur Respir J 2001; 17: 733-746.
\end{abstract}

There is growing international concern regarding the adverse health effects of air pollution. Pollution is becoming an important public health problem and political issue, due to the rapid growth in world population and the increasing world-wide migration from rural to urban areas [1]. Recent United Nations estimates have indicated that $47 \%$ of the global population is living in urban areas. This urbanization has brought with it an increased need for transportation and hence an increase in motor vehicle generated air pollutants. However, a large number of epidemiological studies from different parts of the world have consistently identified an association between ambient levels of air particles and various health outcomes, including mortality, exacerbation of asthma, chronic bronchitis, respiratory tract infections, ischaemic heart disease and stroke [2]. Indeed, the United Nations Environment Programme has identified particulate matter pollution as the most serious air pollution problem faced by many cities [3]. It is therefore important to evaluate the health effects of motor vehicle generated pollutants in mechanistic studies, in order to under-

\begin{abstract}
*Unit for Experimental Asthma \& Allergy Research, The National Institute of Environmental Medicine, Karolinska Institutet, Stockholm, Sweden. \#Dept of Respiratory Medicine and Allergy, University Hospital, Umeå, Sweden. "Respiratory Cell and Molecular Biology Research Division, Southampton General Hospital, Tremona Road, Southampton, UK.
\end{abstract}

Correspondence: S-E. Dahlén, Unit for Experimental Asthma \& Allergy Research, The National Institute of Environmental Medicine, Karolinska Institutet, SE-171 77 Stockholm, Sweden.

Fax: 468300619

Keywords: Air pollution, allergy incidence, animal studies, asthma exacerbation, diesel, human exposure

Received: October 52000

Accepted after revision October 202000

The authors were supported by the Swedish Heart and Lung Foundation, The Medical Research Council (project No 9071), the Swedish National Road Administration (Vägverket) and The Foundation for Health Care and Allergy Research (Vårdal). stand the relevance of associations found in the epidemiological studies. This overview is based on a literature search including papers published up to the first quarter of the year 2000. Much of the research on the adverse effects of diesel exhaust, both in vivo and in vitro, has been conducted in animals. Such experimental studies are reviewed critically and the findings are compared with those in human studies.

\section{Diesel emission}

Of the motor vehicle generated air pollutants, diesel exhaust particles (DEPs) account for a highly significant percentage of the particles emitted in many towns and cities [3,4]. Complete combustion of diesel fuel produces water and carbon dioxide, but use of diesel in motor vehicles normally results in incomplete combustion and the formation of various gases, liquids and solid particles. Compared with petrol engines, diesel engines produce far less carbon monoxide, but give rise to a greater amount of nitrogen oxides and aldehydes, 
which are particularly prone to cause irritation of the upper respiratory tract. Diesel engines also produce submicron soot particles that are believed to mediate several of the observed adverse effects. It has been estimated that the particulate emission from diesel engines per travelled distance is over 10 times higher than the emission from petrol engines of equivalent power running on unleaded petrol, and over 100 times higher than that from petrol engines fitted with catalytic converters $[5,6]$.

The dose of particle deposited in the lung depends on their concentration in the inhaled air and their size. Particles with a diameter $<5 \mu \mathrm{m}[7,8]$ reach the alveoli and are deposited there, whereas particles larger than 5 $\mu \mathrm{m}$ only reach the proximal airways and are eliminated by mucociliary clearance. Previous human studies using radioactive particles have demonstrated that $83 \%$ of particles with a mass median diameter of $2.5 \mu \mathrm{m}$ are deposited in the lung, whereas only $31 \%$ of particles of $11.5 \mu \mathrm{m}$ are deposited [9]. Recent electron microscopy studies suggest that over $80 \%$ of DEPs have a size $\leqslant 0.1$ $\mu \mathrm{m}$; DEPs consist of a carbonaceous core similar to carbon black, onto which an estimated 18,000 different high-molecular-weight organic compounds are adsorbed [2]. Diesel exhaust (DE), in addition to DEPs, contains a complex mixture of gases such as carbon monoxide (CO), nitric oxides $\left(\mathrm{NO}, \mathrm{NO}_{2}\right)$, sulphur dioxide $\left(\mathrm{SO}_{2}\right)$, hydrocarbons, formaldehyde, transition metals and carbon particles [10]. Regarding the health effects, recent focus has been on ultrafine particles (diameter $<0.05-0.10 \mu \mathrm{m}$ ). They are highly reactive and are present in large numbers in the urban environment. They are able to penetrate the epithelium and vascular walls and enter the bloodstream. It has been hypothesized that ultrafine particles account for the systemic effects of DEPs, such as increased carcinogenicity [11], potentiation of autoimmune disorders [12], alterations in blood coagulability and increased cardiovascular disorders $[13,14]$.

\section{Air pollution as a cause of increased asthma and allergy?}

Parallel to the increase in air pollution, there has also been a rapid increase in the global incidence of allergic diseases such as asthma and rhinitis in the last two decades, which cannot be attributed to genetic changes, and is assumed to be related to changes in environmental factors [15]. Observations in Japan have suggested that children living close to roads with heavy traffic are more likely to develop allergies [15]. Recent epidemiological data support the theory that atopic children may constitute a group of individuals that run a heightened risk of developing negative health effects following exposure to airborne particles [16]. The existence of such sensitive subgroups amongst the general population would seem to deserve particular attention for risk assessment. This review has identified several effects of DEPs on immunological or inflammatory systems that may potentially have particular relevance for a role of chronic diesel exhaust exposure in the pandemic of allergic disease.

Irrespective of whether or not vehicle generated pollutants contribute to the increased numbers of sensitized individuals in urban areas, patients with airway diseases such as asthma have been found more adversely affected than the normal population to inhalation of air pollution components $[17,18]$ and in particular acid aerosols [19]. Various studies have shown that overall lung deposition is increased in patients with obstructed airways [20-22]. For example, a $30 \%$ reduction in airway cross-sectional area results in a deposition increase in the bifurcating airways of $>100 \%[2,23]$. There is also an interesting case-report of DEPs alone causing asthma [24]; three nonsmoking railroad workers, without any previous history of asthma, developed persistent asthma after acute exposure to excessive levels of DE. This was registered in a situation where two locomotive units were coupled together and the crew riding in the second locomotive unit were exposed for 2-5 h to significant levels of DE. All three subjects developed asthma, which persisted 1-3 yrs after exposure. Although the actual levels were never measured, it is likely that such excessive exposure rarely occurs even in occupational situations.

\section{Experimental studies of diesel emissions}

\section{Human subjects}

Exposure challenge studies. Experimental human exposure studies have mainly been carried out using exposure chamber set-ups with controlled DE challenges. It is critical to ensure that the method is designed so as to maintain a certain relationship between the particulate and gaseous components and to obtain particles of the same size and chemical properties throughout the exposure series. A unique and carefully validated system for exposures has been particularly useful [25, 26]. The effects of such diesel exposures have been evaluated in humans using symptom questionnaires, lung function measurements and bronchoscopy with biopsy sampling and airway lavage.

In one study, healthy volunteers were exposed to DE, with a $\mathrm{NO}_{2}$ concentration of 1.5 parts per million (ppm). Bronchoalveolar lavage (BAL) $18 \mathrm{~h}$ after DE exposure revealed a significant decrease in the total number of metachromatic cells (mast cells) in the bronchial portion and a significant increase in neutrophils in the bronchoalveolar portion. An increase in the CD4+/CD8+-ratio was found in the bronchoalveolar portion, along with a reduced phagocytosis rate by alveolar macrophages in vitro [26].

In another study on healthy volunteers, symptoms and lung function responses to DE were assessed. All the exposed subjects reported an unpleasant smell and eye irritation but there was no alteration in the lung function tests measured as forced expiratory volume in one second (FEV1) [25]. Two other studies [21, 26], investigated whether the use of a particle trap on the tail pipe of an idling diesel engine would reduce the DEinduced effects on symptoms, lung function and airway inflammation, compared to effects induced by unfiltered DE. Exposure to DE without a filter caused increases in symptoms and airway resistance as well as airway inflammation with BAL neutrophilia. Macrophage phagocytosis was reduced. The particle trap 
reduced the number of particles by $46 \%$ but there was no significant difference in symptoms, lung function or in BAL neutrophil numbers after DE with or without the trap [26]. Therefore, for these effects, the relative importance of DEPs and other components of DE has yet to be established.

In a recent study [27], filters intended for use in the air intake into the passenger compartment of vehicles were tested for their ability to prevent DE effects. Thirty-two healthy nonsmoking subjects were exposed for $1 \mathrm{~h}$ in a specially designed exposure chamber, once to air and once to unfiltered DE and subsequently to DE filtered with four different air intake filters. The exposure level was $300 \mu \mathrm{g}$ of particles with a $50 \%$ cut-off aerodynamic diameter of $10 \mu \mathrm{m}$ per cubic metre (PM10 $300 \mu \mathrm{g} \cdot \mathrm{m}^{-3}$ ). The study included measurements of lung function, symptoms and nasal responses. It proved possible to distinguish differences in efficacy between the filters, all of which gave air quality superior to the unfiltered exhaust. While no acute effects were seen on nasal lavage, rhinometry and lung function (measured as FEV1 and FVC), there were major effects on symptoms. The use of a particle filter in combination with an active charcoal filter was demonstrated to give significantly better results than the other filters.

The effect of a high ambient concentration of DE $\left(300 \mu \mathrm{g} \cdot \mathrm{m}^{-3}\right)$ on various airway parameters including cells and soluble components was assessed [28]. The results showed an increase in neutrophils, mast cells, CD3+, CD4+ and CD8+ T-lymphocytes in the airway mucosa, along with upregulation of adhesion molecules intracellular adhesion molecule (ICAM)-1 and vascular cell adhesion molecule (VCAM)- 1 in the vascular endothelium $6 \mathrm{~h}$ after exposure to DE. In addition, increased numbers of cells expressing leukocyte function associated antigen (LFA)-1 (the ligand for ICAM-1) were found. This inflammatory response was an order of magnitude greater than the effects documented after allergen challenge in atopic asthmatics [29, 30] indicating a pronounced signal for inflammatory cell recruitment as a response to DE exposure. This upregulation of endothelial and leukocyte adhesion molecules provides a mechanism for the influx of inflammatory cells into the airways. Furthermore, immunohistochemical staining for cytokines has shown enhanced expression of interleukin (IL)-8 and growth related oncogene (GRO)- $\alpha$ in the airway epithelium, which can also play a role in the recruitment of inflammatory cells after exposure to DE [31]. The increase in neutrophils in the airway mucosa following exposure to DE was also evident in the bronchial wash, whereas the increase in the number of submucosal mast cells did not correspond to any changes in the number of metachromatic cells (mast cells) in the lavages. However, an elevated concentration of methyl-histamine detected in the BAL after exposure to DE supports increased degranulation of mast cells [28]. In contrast to the pronounced inflammatory response detected in the airways, lung function parameters were found unaffected following exposure to DE [28]. Consequently, lung function measurements alone cannot be used to exclude adverse air-pollution-associated airway responses.

These pronounced airway inflammatory responses were detected at a fairly high $\left(300 \mu \mathrm{g} \cdot \mathrm{m}^{-3}\right)$ concentration of DE. In order to evaluate if exposure to a lower concentration (more similar to relevant exposure concentrations in ambient air), would induce a similar response, healthy and asthmatic subjects have been exposed to DE with a PM10 concentration of 100 $\mu \mathrm{g} \cdot \mathrm{m}^{-3}$ for $2 \mathrm{~h}$. Bronchoscopy with biopsy sampling, bronchial wash and BAL was performed $6 \mathrm{~h}$ after the end of the exposure. Data from this study are forthcoming.

Studies of induced sputum have also been used to evaluate DE effects on the human airways [32]. Sixteen healthy nonsmoking subjects were exposed to air and DE at a particle concentration of $300 \mu \mathrm{g} \cdot \mathrm{m}^{-3}$ for $1 \mathrm{~h}$. Sputum induction was performed 6 and $24 \mathrm{~h}$ after each exposure. Six hours after exposure to DE, a significant increase was found in neutrophil percentage of total cells in sputum, together with an increase in the concentration of IL- 6 and methyl-histamine, compared to control air exposures.

In summary, these data confirm that the acute mediator and cytokine responses, together with the enhanced expression of the vascular adhesion molecules in the airway mucosa, may represent an early stage in the inflammatory response following exposure to DE, and be of importance in the development of the DE induced airway inflammation. The results further suggest that the DE concentration is an important factor to take into account when evaluating the time course of DEPs-induced airway inflammation.

Nasal challenge studies. DEPs have been shown to potentiate immunoglobulin-E (IgE) production in human respiratory mucosal membranes. DiAz-SANCHEZ [33] performed a study in which nasal DEP challenges at various doses were used to investigate the effect on localized immunoglobulin production. Four days after challenge with $0.3 \mathrm{mg}$ DEPs a significant increase in nasal $\mathrm{IgE}$, but not in other immunoglobulin classes, was detected. There was also an increase in the number of $\operatorname{IgE}$ secreting cells in nasal lavage, but no increase in immunoglobulin-A (IgA) secreting cells.

Human nasal provocation studies have shown that DEPs can act as an adjuvant to allergen. Nasal challenge was performed with DEPs $(0.3 \mathrm{mg})$, the ragweed allergen Amb a $I$, or both, in a group of ragweedsensitive subjects [34]. Ragweed challenge alone demonstrated an increase in IgE and immunoglobulin-G4 (IgG4) as well as ragweed-specific $\operatorname{IgE}$ in the lavage fluid. However, after challenge with allergen and DEPs there was a sixteen-fold increase in ragweed-specific IgE. DEPs alone increased total IgE, but in combination with allergen there was an increase in antigenspecific IgE and in expression of Th0 and Th2-type cytokines (IL-4, IL-5, IL-6, IL-10 and IL-13). It is currently believed that such deviations of the immune system may have a crucial role for the development of an atopic response [35]. These studies suggest that DEPs can enhance B-cell differentiation. By initiating and elevating IgE production, DEPs may theoretically play a role in the increased prevalence of allergic disease.

Nasal challenge with a combination of DEP and allergen has been shown to induce larger ragweedspecific IgE and $\mathrm{IgG} 4$ responses compared with DEP 
alone but with similar total IgE levels [36]. There was also a change in the cytokine pattern, favouring allergic sensitization. The authors propose that synergism between DEP and natural allergens is a key feature in increasing allergen induced respiratory allergic disease.

There is also evidence of DEPs inducing IgE isotype switching. FuJIEDA et al. [37] exposed human volunteers, by nasal challenge, to DEPs together with ragweed allergen. There was a local increase in IgE production, cytokine production and an even greater increase in mucosa-specific ragweed IgE production. The isotype switching occurred only when DEPs and allergen exposure was combined. The findings suggest that increasing environmental DEPs with the same environmental load of allergen could be a factor behind the increasing sensitization and prevalence of allergic asthma.

Healthy, nonsmoking human volunteers have been exposed to DEPs by intranasal instillation and cytokines in nasal lavage were estimated after $18 \mathrm{~h}$ by an indirect approach (messenger riboneucleic acids mRNA) [38]. Before challenge, most subjects had detectable mRNA levels of only a few cytokines (Interferon IFN- $\gamma$, IL-2 and IL-13), while after challenge with $0.3 \mathrm{mg}$ DEPs, these three and a number of additional cytokines (IL-4, IL-5, IL-6 and IL-10) were seen in increasing levels. Increase in such nasal cytokine expression after DEP exposure could again contribute to enhanced local IgE production.

Taken together, these studies suggest that DEPs have the ability to induce IgE responses directly by acting on B-cells and indirectly by enhancing the opportunity for cytokine production. DEPs in combination with allergens are able to generate a Th2-type cytokine response and thus favour the production of allergen-specific IgE. It has therefore been proposed that DEPs can enhance B-cell differentiation and, by initiating and enhancing $\operatorname{IgE}$ production, they may be of importance in the increased incidence of allergic airway diseases [34].

\section{Animals}

Some general points must be raised regarding animal studies. Apart from the possibility that mechanisms may be very different from those in man, studies using radioactive particles have also demonstrated that there is a large difference in the dosimetry of the small airways of rodents compared to humans. Therefore, care must be taken when extrapolating animal data to humans. Certainly, for ozone at least, it has been shown that in order to elicit the same response in rodents as in humans, several times higher concentrations are required [39]. In addition, in many studies on animals, the doses of DE are much higher than those humans are exposed to in daily life. Measurements in the Scandinavian countries have shown that the average 24-h particulate matter concentration varied from 30 $150 \mu \mathrm{g} \cdot \mathrm{m}^{-3}$ total suspended particles (TSP). However, in certain industrial areas, concentrations of up to 1,500 $\mu \mathrm{g} \cdot \mathrm{m}^{-3}$ have been measured. In Stockholm for example, 1 - $\mathrm{h}$ mean values $300-500 \mu \mathrm{g} \cdot \mathrm{m}^{-3}$ have been found at kerbsides and maximum levels of almost $600 \mu \mathrm{g} \cdot \mathrm{m}^{-3}$ have been reached in a tunnel in the centre of the city [40].
Exposure studies in rats. Long-term studies looking at the effects of DE exposure in rats have demonstrated increased accumulation of particles and aggregates of particle laden macrophages in the alveoli and peribronchial interstitial tissues, as well as local inflammation, epithelial proliferation, fibrosis and emphysematous lesions.

For example, rats were exposed to DE for 30 months [41] and examined at 6 month intervals by electron microscopy. Changes consistent with anthracosis were seen after 6 months exposure at a concentration of $1,000 \mu \mathrm{g} \cdot \mathrm{m}^{-3}$. There were foci of diesel particle laden alveolar macrophages. DEPs were found in type 1 epithelial cells and there was also hypertrophy and proliferation of type 2 cells. An infiltration of particle laden macrophages, neutrophils, mast cells and plasma cells in the interstitium of the alveolar septa was also seen. The most prominent changes, however, were focal shortening of cilia and the protrusion of nonciliated cells.

MoHr et al. [42] compared the effects of inhaled $\mathrm{DE}$ with those of coal oven gas mixed with pyrolyzed pitch. Three groups of rats were exposed to clean air, filtered DEPs or unfiltered DEPs $\left(4,000 \mu \mathrm{g} \cdot \mathrm{m}^{-3}\right)$. Another group was exposed to coal oven flue gas mixed with pitch fumes pyrolyzed under nitrogen. Most of the DEP-exposed animals had deposits consisting of large amounts of carbonaceous particles phagocytozed by alveolar macrophages and this was associated with severe chronic inflammation, alveolar septal thickening, bronchiolo-alveolar hyperplasia and alveolar lipoproteinosis. Rats exposed to coal oven flue gas had much less severe inflammatory changes.

In a study exposing rats to increasing concentrations of DEPs $\left(350-7,000 \mu \mathrm{g} \cdot \mathrm{m}^{-3}\right)$, for up to 24 months [43], a progressive increase in the lung burden of particles was seen at the higher DEP concentrations. Tracheal mucociliary transport was not affected, but there was a significant prolongation of long-term pulmonary clearance half-times in the two groups that were exposed to the highest concentrations of DEPs.

DEPs cause dust overloading and impairs pulmonary clearance at high doses in both rat and man. There appears to be a threshold above which particle retention and inflammation occurs. It has been calculated, mostly on the basis of evidence from animal studies, that the threshold is $\sim 500 \mu \mathrm{g} \cdot \mathrm{g}^{-1}$ lung tissue [44]. However, it is difficult to assess how this correlates to levels in the inhaled air, and there may be important interactions between the actual concentration and the duration of the exposure. After acute exposure to a high concentration of DEPs $\left(5,700 \mu \mathrm{g} \cdot \mathrm{m}^{-3}\right.$ for 3 days $)$ the particles were found to be eliminated efficiently [45]. There was a rapid initial increase in the elimination followed by a decline in macrophage burden. A chronic low dose $\left(50 \mu \mathrm{g} \cdot \mathrm{m}^{-3}\right.$ of DEPs; exposure for 52 weeks) was also cleared relatively efficiently. More than $80 \%$ of the inhaled DEPs had been eliminated $1 \mathrm{yr}$ after the exposure. However, comparison showed that animals exposed to the higher concentrations cleared more of the total lung burden than those exposed chronically to low concentrations. At the longer low concentration exposure, the macrophage burden was relatively greater and associated with a steady development of lung 
maculae, suggesting that continuous low dose exposure may be more detrimental than acute high dose exposure.

Taking these experimental findings into account, a mathematical model for the prediction of lung burden and alveolar clearance in rats has been constructed [46]. At low lung burdens, the alveolar clearance rate of diesel soot was calculated to be constant and due to macrophage elimination via the mucociliary transport system, whereas at high lung burden, the alveolar clearance appears to be determined principally by the capacity for transport to the lymphatic system. It should be recognized however that the elimination of particles from central and peripheral airways may be vastly different and partly dependent upon the tidal airflow during the exposure. Recent data in humans suggest that elimination from the peripheral airways may be considerably slower than previously thought [47].

Exposure studies in cats. A group of cats was exposed to DEPs for $>2$ yrs [48]. Their exposure was divided into two periods. During the first period, which lasted 61 weeks, $6,000 \mu \mathrm{g} \cdot \mathrm{m}^{-3}$ of DEPs was used. At this point, no changes in the lungs were evident. During the following 62 weeks, a higher concentration of 12,000 $\mu \mathrm{g} \cdot \mathrm{m}^{-3}$ DEPs was used and after the $2 \mathrm{yrs}$, a pattern of restrictive lung disease had developed.

In another similar study, cats were exposed to DEPs and $\mathrm{NO}_{2}$ for over 2 yrs. After 62 weeks, the concentration of DEPs had increased from $6,340-11,700 \mu \mathrm{g} \cdot \mathrm{m}^{-3}$ and the concentration of $\mathrm{NO}_{2}$ from $2.68-4.37 \mathrm{ppm}$ [49]. Morphological changes were seen, mainly in the proximal acinar regions of lungs, with peribronchial fibrosis, bronchiolar metaplasia, increased numbers of lymphocytes, fibroblasts and interstitial macrophages containing DEPs. The study indicated a persistent fibrogenic effect on the proximal acinar region of the lungs following long-term DE.

Intratracheal exposure studies of diesel exhaust particles in mice. In a study of in vivo toxicity of DEPs in the ICR mouse strain [50], an acute intratracheal instillation of DEPs $\left(400-1,000 \mu \mathrm{g} \cdot \mathrm{mouse}^{-1}\right)$ was found to cause severe lung injury and high mortality. The cause of death was pulmonary oedema mediated by endothelial cell damage. The toxicological effect and the increased mortality were to a great extent prevented by pretreatment with the oxygen radical scavenger superoxide dismutase (SOD), supporting the hypothesis that DEP toxicity is connected to production of the radical superoxide $\mathrm{O}_{2}^{-1}$ leading to endothelial cell damage.

Studies of developing lung in the rat. Studies on humans in different geographical areas have raised the concern that children and the elderly may be particularly susceptible to the harmful effects of air pollution. In support of this, there have also been studies indicating the possibility of impaired lung development in animals exposed to oxidant gases or inhaled toxicants early in life. In one study which aimed to investigate this, rats were exposed to $\mathrm{DE}\left(3,500 \mu \mathrm{g} \cdot \mathrm{m}^{-3}\right), \mathrm{NO}_{2}$ $(9.5 \mathrm{ppm})$, or to air as a control [51]. One group, which represented a developing lung model, was exposed first in utero (by exposing the mother from conception and throughout gestation) and then from birth up to 6 months of age. Another group, representing an adult model, was exposed between the ages of 6 and 12 months. It was found that DEPs altered the airway fluid constituents and tissue collagen in both groups. Interestingly, in the adult group, there was a six-fold increase in neutrophils as well as increased cellularity in the lung-associated lymph nodes, delayed clearance of particles and an increase in lung weight. However, none of these changes were seen in rats exposed during development. In adult rats there was also a focal aggregation of sootladen alveolar macrophages, but only scattered individual macrophages were found in the young rats. The authors concluded that there was no evidence for developing rats being more susceptible to the toxic effects of $\mathrm{NO}_{2}$ or DE; if anything, the data would indicate that developing rats may be less sensitive.

Studies in animals with experimental lung disease. Epidemiological studies have indicated that subjects with pre-existing lung disease may be more susceptible to episodic high levels of airborne pollutants than normal subjects [52]. This has been studied in a rat model [53], in which pulmonary emphysema was induced in rats by intratracheal instillation of the proteolytic enzyme elastase, and manifested as enlarged alveoli, alveolar ducts and ruptured alveolar septa. These structural changes were not by themselves associated with inflammation or alterations of bronchioles. The emphysematous rats and a group of control rats were then exposed for 24 months to DE $\left(3,500 \mu \mathrm{g} \cdot \mathrm{m}^{-3}\right), \mathrm{NO}_{2}(9.5 \mathrm{ppm})$, or air as control. Different parameters were measured such as lung burden of diesel soot particles, respiratory function, BAL fluid composition, clearance of radiolabelled particles, pulmonary immune response, lung collagen, excised lung weight and volume, and histopathology. The hypothesis was that the effects of pre-existing emphysema and long-term DE exposure on lung function and morphology were additive. The results, however, showed that rats with experimentally induced emphysema were no more susceptible to inhalation of $\mathrm{NO}_{2}$ or DE than control rats. In fact, fewer soot particles accumulated in the emphysematous lungs [53, 54].

Intraspecies comparative studies. Morphological changes have also been examined in a comparative study of Cynomolgus monkeys and rats. Both animal species received four different exposures for 24 months: DEPs $\left(2,000 \mu \mathrm{g} \cdot \mathrm{m}^{-3}\right)$, coal dust $\left(2,000 \mu \mathrm{g} \cdot \mathrm{m}^{-3}\right)$, a combination of DEPs and coal dust $\left(1,000 \mu \mathrm{g} \cdot \mathrm{m}^{-3}+1,000\right.$ $\left.\mu \mathrm{g} \cdot \mathrm{m}^{-3}\right)$ or ambient air [55]. It was found that monkeys retained relatively more particulate matter than rats. The sites of particle retention were the same for DEPs, coal dust and the DEPs/coal dust combination. Rats retained more material in the lumen of alveolar ducts and alveoli, whereas monkeys retained more in the interstitium. Rats showed significant alveolar epithelial hyperplasia, inflammation and septal fibrosis. In contrast, such morphological changes were not seen in the monkeys. The results indicate that particle retention patterns and tissue reactions in 
rats exposed to DEPs may not be predictive of the reactions in primates [56]; primates may retain more DEPs, but may also be less sensitive to the harmful effects.

\section{Immunology and allergy}

\section{In vivo studies}

To study the effect of DEP on the accumulation of particles in lung-associated lymph nodes and the effect on antibody responses after immunization, rats and mice [57] were exposed to varying doses of DEPs (350 $7,000 \mu \mathrm{g} \cdot \mathrm{m}^{-3}$ ) for 24 months. Control and exposed animals were immunized, by intratracheal instillation of sheep red blood cells, after exposure at $6,12,18$, and 24 months. Pathological changes were maximal after 1824 months at 3,500 or $7,000 \mu \mathrm{g} \cdot \mathrm{m}^{-3}$ exposure levels. Microscopic findings were: increase in particle content of alveolar macrophages; concentration of macrophages closer to terminal bronchioles; wall fibrosis; bronchial metaplasia; and, in some cases, squamous metaplasia. There were cholesterol clefts and increased numbers of interstitial neutrophils and intra-alveolar granular eosinophilic material with entrapped free particles. Lung-associated lymph nodes were blackened and enlarged due to clusters of DEPs. There was increased cellularity in rats exposed to the highest dose. However, the levels of specific antibodies were not significantly changed.

DEPs showed an adjuvant activity on IgE production in mice. Mice injected intraperitoneally with ovalbumin (OA) mixed with DEP showed higher IgE levels than mice immunized with $\mathrm{OA}$ alone. In addition, Japanese cedar pollen (JCPA) specific IgE production could be seen in mice immunized with JCPA mixed with DEPs, but not in animals immunized with JCPA alone [58]. In another study [59], DEPs and carbon black were instilled intranasally in mice and the animals were then exposed to JCPA. There was a significant adjuvant effect of the particles on JCPA specific IgE and IgG production.

In order to elucidate whether the carbon core of the DEPs or the adsorbed organic substance is responsible for the effect [60], mice were immunized four times with either OA, OA with DEPs or OA with carbon black (carbon black). Specific IgE for OA was then analysed. Both DEPs and carbon black showed an adjuvant activity for specific IgE production after intranasal instillation, indicating that they were both responsible for the effect. There have also been other studies which have demonstrated this effect in mice [61].

A difference in antibody response between acute and chronic exposure to DEP was suggested in a study using combined intratracheal inoculations of DEPs and antigen in mice. Increased airway inflammation, and antigen specific $\mathrm{IgG} 1$, were seen after 6 weeks [62], whereas a longer exposure (9 weeks) was required before there was a detectable increase in antigen specific IgE.

When mice were injected intratracheally with OA alone or together with DEPs [63], there was no significant adjuvant activity of IgE production by DEPs ( 50 $\mu \mathrm{g})$. However, the degree of eosinophilic inflammation in the airway corresponded to specific $\operatorname{IgG} 1$ production. In another study, the combination of sensitization to allergen together with diesel exposure, led to enhanced infiltration of eosinophils and neutrophils and also an increment of goblet cells, together with enhanced airway resistance and IL-5 and IgG1 production, but not IgE production. DE alone did not induce pathological changes [64]. Other studies carried out with higher doses of DEPs $(300 \mu \mathrm{g})$ under similar conditions have demonstrated an increase in specific $\operatorname{IgE}$ [65]. Together with the aforementioned studies, this suggests that this response may be dose and time dependent. In ICR mice exposed to DEPs by intratracheal instillation, an increase in epithelial eosinophils, lymphocytes and goblet cells was seen, together with increased production of $\mathrm{IgG}$ and $\mathrm{IgE}$ and the proallergic cytokines IL-2, IL-4, IL-5 and granulocyte macrophage colocny stimulating factor (GM-CSF), but not interferon (IFN)- $\gamma$ [62]. The combination of DEPs and OA has also been shown to increase the bronchoconstriction response to inhaled acetylcholine [66]. Furthermore, daily inhalation of DEPs may enhance the allergen response, possibly by increased local expression of proinflammatory cytokines such as IL-5 and GM-CSF [67]. In one study, increased IgE production was also seen in mice after intranasal administration of suspended particulate matter (SPM) together with $\mathrm{OA}$ at 3-week intervals for a period of 21 weeks [68].

To study the effect of DEPs on allergen-induced bronchial hyperresponsiveness, mice were sensitized to $\mathrm{OA}$ and then exposed to DE $\left(3,000 \mu \mathrm{g} \cdot \mathrm{m}^{-3}\right)$ [69]. Three weeks after DEPs exposure, they were challenged with OA. DE exposure, combined with antigen challenge, induced airway hyperresponsiveness and airway inflammation, including increased numbers of eosinophils and mast cells in the lung tissue. DEP exposure alone also increased airway hyperresponsiveness, but there was no eosinophil infiltration. In a similar set-up, diesel inhalations $\left(3,000 \mu \mathrm{g} \cdot \mathrm{m}^{-3}\right)$ in combination with OA sensitization increased the number of goblet cells in lung tissue, caused increased respiratory resistance and increased immune response measured as specific IgE, IgG1 and IL-5 in the lung tissue [70].

A rhinitis model in guinea pigs was used to study short-term effects of DE $(3 \mathrm{~h}$ exposure at 1,000 and $3,200 \mu \mathrm{g} \cdot \mathrm{m}^{-3}$ ) [71]. Following diesel exposure alone, there was no induction of sneezing, nasal secretion or congestion. However, DEPs augmented the sneezing and nasal secretion induced by histamine, but had no significant effect on histamine-induced nasal congestion, suggesting that acute exposure to high levels of DE may cause nasal mucosal hyperresponsiveness, but no overt symptoms of rhinitis. Hiruma et al. [72] also reported effects of DEPs on the nasal mucosa of guinea pigs consistent with the development of nasal hyperreactivity. It was found that diesel exposure led to a dose dependent increase in histamine-induced vascular permeability, an increased eosinophilic infiltration into the epithelial layer and also enhanced nasal reactivity to histamine.

The mechanisms involved in asthma and allergy development after DEPs exposure may include increased penetration of allergen across the respiratory mucosa or direct modulation of the immunological 
response [73]. Particulate air pollution includes particles from diesel and gasoline engine exhaust and biological materials such as plant debris and tyre debris e.g. latex, that may be allergens [74]. Some allergens, such as the major grass pollen Lolium perenne -1 (Lol p1) allergen, are also shown to specifically bind to DEPs. This might be a possible mechanism for the triggering of asthma attacks and a theoretical contributing factor to the increase in asthma prevalence [75].

ORMSTAD et al. [76] have studied the allergen carrying effect of DEP. This was an in vitro study of allergen adsorption to particles such as indoor-suspended particles matter (SPM) and DEPs. They reported that the cat allergen $(\mathrm{Fel} \mathrm{d1})$, dog allergen $(C a n f 1)$ and birch pollen allergen (Bet $v 1)$ could all be found on the surface of SPM, whereas house dust mite allergen (Der $p 1)$ was not. However, all four allergens were found to be absorbed to DEPs. A chemical characterization of the coating of Birch pollen grains collected during pollen season in the north of Stockholm has been published [77]. The greatest portion $(80 \%)$ consisted of n-alkanes and n-alkenes, but methylketones, ethers, alcohols and amino alcohols were also identified.

In vitro studies. Some in vitro studies have been performed on animal cells, but most of the work has been conducted on cells derived from humans. The eosinophil is a major effector cell in allergic inflammatory disorders. In one study, the effects of DEPs and DEP extract on eosinophil adhesion, survival rate and degranulation were assessed [78]. Eosinophils, human mucosal microvascular endothelial cells (HMMECs) and human nasal epithelial cells (HNECs) were preincubated with and without DEP extract. Radiolabelled eosinophils were allowed to adhere to monolayers of HMMECs and HNECs with the degree of reactivity being determined after washing, and the numbers of adherent eosinophils were calculated. There was a significant increase in the adhesiveness of eosinophils to HNECs, but not HMMECs. DEP also induced eosinophil degranulation without changing the eosinophil survival rate. These results would indicate that DEPs play a significant role in the promotion of nasal hypersensitivity induced by enhanced eosinophil infiltration and degranulation.

The cytotoxicity of DEP-induced phagocytosis and the resulting immune response were studied in human bronchial and nasal epithelial cell cultures [79]. DEPs exposure induced a time and dose-dependent membrane damage. Transmission electron microscopy showed that DEPs underwent endocytosis by epithelial cells and translocated through the epithelial cell sheet. Flow cytometric measurements allowed establishment of the time and dose dependency of this phagocytosis and its lack of specificity for different particles (DEPs, carbon black and latex were tested). DEPs led to a timedependent increase in IL-8, GM-CSF and IL-1 beta release. This inflammatory response occurred later than phagocytosis and it appeared to depend on the types of adsorbed compounds, as in this study carbon black had no effect on cytokine release.

Airway epithelial cells play a prominent role in the pathogenesis of respiratory disease. Studies have shown that exposure of nasal or bronchial epithelial cells to DEP results in increased synthesis and release of proinflammatory mediators, cytokines such as IL-6, IL8 or GM-CSF, and adhesion molecules [80].

In line with the observations during nasal challenge in vivo $[36,38]$, studies on isolated human B-lymphocytes have demonstrated enhanced IgE synthesis following exposure to DEPs [81]. In a study of purified human B-cells stimulated by IL-4, the ability of DEPs to induce IgE production could be mimicked by polyaromatic hydrocarbons (PAH) extracted from DEPs. However, DEP-PAH did not induce IgE production in unstimulated B-cells, indicating that it only enhances ongoing IgE production. Phenanthrene, a major polyaromatic hydrocarbon and an important component of DEPs, has shown the same enhancing effect on $\operatorname{IgE}$ production in a human B cell line [82].

The effect of DEP-PAH on the release and mRNA expression of IL-8, monocyte chemotactic peptide-1 (MCP-1) and RANTES (Regulated on activation normal T cell expressed and secreted) was investigated by paripteral blood mononuclear cells (PBMCs) obtained from healthy subjects. The production of protein in supernatants was assessed by enzyme linked immunoabsorbent assay (ELISA), and mRNA production by semiquantitative reverse transcriptase polymerase chain reaction (RT-PCR). There was a dose dependent increase in the secretion of IL-8 and RANTES in response to increasing concentrations of DEP-PAH (range $0.5-50 \mathrm{ng} \cdot \mathrm{mL}^{-1}$ ). However, there was a significant dose dependent inhibition of MCP-1 secretion. The expression of mRNA coding for IL-8, RANTES and MCP-1 showed variations that parallelled the production of the corresponding proteins. These results suggested that DEP-PAH can modulate chemokine pathways at the transcriptional level [83].

Other studies have been performed using cultured human bronchial epithelial cells (HBEC) exposed to DEPs [84]. Exposure of these cells to DEP at 50 $\mu \mathrm{g} \cdot \mathrm{mL}^{-1}$, filtered DEPs solution or DEP at $100 \mu \mathrm{g} \cdot \mathrm{mL}^{-1}$ attenuated the ciliary beat frequency $(\mathrm{CBF})$ dose dependently and increased the release of IL-8, GMCSF and soluble ICAM-1 (s/CAM-1). The observations support the hypothesis that DEPs exposure may lead to functional changes and the release of proinflammatory mediators with the potential to influence the development of airway disease. Specifically, infiltration of neutrophils and other inflammatory cells would be promoted by the observed changes.

In another report, the effect of DEPs on the CBF, and production of IL-8, GM-CSF, RANTES and sICAM-1 by cultured human bronchial cells was compared between nonatopic, nonasthmatic subjects and atopic patients with mild asthma. Bronchial cells from these two groups were exposed to $10-100 \mu \mathrm{g} \cdot \mathrm{mL}^{-1} \mathrm{DEP}$ for $24 \mathrm{~h}$. The baseline CBF was the same in both groups. There was a significant attenuation in the $\mathrm{CBF}$, in response to increasing DEP levels in both groups, with the largest changes at $100 \mu \mathrm{g} \cdot \mathrm{mL}^{-1}$. The cell cultures from asthmatics constitutively released significantly greater amounts of IL-8, GM-CSF and SICAM-1 and were the only cultures to release RANTES. In response to $10 \mu \mathrm{g} \cdot \mathrm{mL}^{-1}$ of DEP, there was a significant increase in the release of IL-8, GM-CSF and sICAM-1 
in cells from asthmatics. However, exposure to doses of 50 and $100 \mu \mathrm{g} \cdot \mathrm{mL}^{-1}$ led to a decrease in the release of IL-8 and RANTES. In contrast, only these higher concentrations of DEPs caused a significant increase in the release of IL-8 and GM-CSF in cells from nonasthmatics. These results suggest that the bronchial epithelial cells of asthmatics are more sensitive than cells from normal subjects to DEPs, and that they are also different with regard to the amounts of proinflammatory mediators released [85].

The effect of DEPs has also been studied in three different in vitro systems of human airway epithelial cells: nasal polyps, bronchial cells obtained at lung tumour resection or at autopsy, and the bronchial epithelial cell line BEAS-2B [86]. DEP $\left(10-100 \mu \mathrm{g} \cdot \mathrm{mL}^{-1}\right)$ induced a dose- and time-dependent stimulation of IL-8 and GM-CSF production by all three kinds of epithelial cells. Using double chamber plates, it was shown that the cells could only be stimulated from the apical side. As a control, neither coal nor graphite showed any stimulatory effect, whereas benzpyrene, a constituent of DEPs, did. Thus it appears that human epithelial cell exposure to DEP might stimulate cytokine production, with possible relevance for the allergic inflammation.

In another investigation, the effect of DEPs in doses $40-330 \mu \mathrm{g} \cdot \mathrm{mL}^{-1}$ was recorded using the human bronchial epithelial cell line, BEAS-2B [87]. DEP diameter ranged $25-35 \mathrm{~nm}$ and the particles were phagocytized by these cells. There was an increase in IL-6 and IL-8 production (11-fold and 4-fold, respectively). Exposure of these cells to tumour necrosis factor (TNF)- $\alpha$ also stimulated a strong increase in IL- 6 and IL- 8 production. There was an additive effect on the production of IL-6 and IL-8 after TNF- $\alpha$ priming and subsequent exposure to DEPs, seen only at low doses of DEPs $\left(10-70 \mu \mathrm{g} \cdot \mathrm{mL}^{-1}\right)$ and TNF- $\alpha\left(0.05-0.2 \mathrm{ng} \cdot \mathrm{mL}^{-1}\right)$.

To elucidate the molecular mechanism of action of DEPs, IL-8 gene expression was studied by northern blot analysis, and run-on transcription assay in human bronchial epithelial cells. Suspended DEPs (1-50 $\mu \mathrm{g} \cdot \mathrm{mL}^{-1}$ ) increased the steady state levels of IL-8 mRNA. Electrophoretic mobility shift assay (EMSA) demonstrated that DEPs induced increased binding to the specific motif of the nuclear transciption factor $\kappa \mathrm{B}(\mathrm{NF}-\kappa \mathrm{B})$, but not of transcription factor AP-1. NF$\kappa \mathrm{B}$ is known to stimulate the trancription of genes coding for inflammatory molecules like TNF- $\alpha$ and IL8 . The luciferase reporter gene assay using wild type and mutated NF- $\mathrm{NB}$ binding sequences showed that DEP-induced NF- $\kappa$ B activation was involved in IL-8 transcription. These results indicate that DEPs activate $\mathrm{NF}-\kappa \mathrm{B}$, which may act as an important mechanism for the increased inflammatory cytokine release [88].

The effects of DEP extract on the expression of histamine $\mathrm{H} 1$ receptor $(\mathrm{H} 1 \mathrm{R})$ mRNA and the production of IL-8 and GM-CSF in human nasal and mucosal microvascular endothelial cells have also been investigated. The change in expression of H1R mRNA was evaluated by RT-PCR and southern blot analysis. The amount of IL- 8 and GM-CSF was measured by ELISA. It was found that DEP led to a significant upregulation of the H1R gene expression as well as an increase in histamine-induced IL-8 and GM-CSF production [89].
YANG et al. [90] studied the possible role of cytokines in the toxic effect of DEPs on rat alveolar macrophages (AM). The macrophages were incubated with DEPs in different concentrations as well as with methanol, washed DEPs or DEP methanol extracts. High concentrations of DEPs and methanol extracts increased IL-1 secretion by AM, while there was no effect on TNF- $\alpha$. DEPs inhibited production of IL-1 and TNF- $\alpha$ stimulated by endotoxin (lipopolysaccharide). The results suggest that the pro-inflammatory cytokine IL-1 may play a role in the pulmonary response to DEP inhalation. The suppressive response of AM pretreated with DEPs, to endotoxin stimulation may be a factor contributing to the impairment of pulmonary defence systems after prolonged DEPs exposure.

In one study, the effect of DEPs on isolated tissues and cultured cells from the respiratory tract of guinea pigs was examined [91]. DEPs induced a dose dependent relaxation of tracheal smooth muscle and time dependent cytotoxicity on tracheal smooth muscle cells and lung fibroblasts. On the basis of pharmacological interventions, it was suggested that the cytotoxicity of DEPs may be mediated via generation of oxygen radicals. DEPs have also been shown to produce aggressive oxygen radicals in a cell-free in vitro system in the presence of appropriate electron donors [92], which in part may explain the potential toxicity and mutagenicity of DEPs.

\section{The role of endogenous nitric oxide}

Nitric oxide (NO) is found in the exhaled air of animals and humans. Increased levels of NO in exhaled air are associated with asthma and airway disease and NO has been observed to suppress Th1 cells leading to a Th2 type response that is associated with allergy [93]. The role of NO in asthma-like symptoms induced by DEPs has been studied in mice [94]. Repeated intratracheal instillation of DEPs in mice induced a four-fold increase in macrophages, neutrophils, eosinophils and lymphocytes in BAL fluid. DEPs induced a two-fold increase of NO in exhaled air and an increase in staining for the enzyme nitric oxide synthetase (NOS) in the airway epithelium. The increase in respiratory resistance induced by the DEP instillation was suppressed by the NOS inhibitor $N^{\mathrm{G}}$ methyl-L-arginine (L-NMA). These findings in mice suggest that some effects of DEPs may be mediated by endogenous NO. In contrast, Muto et al. [95] found that DEP, like L-NMA, abolished the acetylcholine (Ach)-induced relaxation of aortic rings preconstricted with phenylephrine. NO release from aortic rings in response to Ach was inhibited by DEPs $\left(100 \mu \mathrm{g} \cdot \mathrm{mL}^{-1}\right.$, $60 \mathrm{~min}$ ). NO released by the bronchial epithelium in rabbit bronchial strips attenuated the bronchoconstriction induced by Ach and this attenuation was abolished by $60 \mathrm{~min}$ preincubation with DEPs $\left(100 \mu \mathrm{g} \cdot \mathrm{mL}^{-1}\right)$ or L-NMA. Their conclusion was that inhibition of NO release by DEPs may be a part of the observed respiratory effects of DEPs. Clearly further studies are required to establish the significance of these opposite results in two different animal models. 


\section{Cardiovascular effects}

Epidemiological studies have associated increased mortality in cardiovascular diseases with episodes of heavy air pollution [96, 97]. SEATON et al. [14] suggested that the ultra fine particles would induce airway inflammation in susceptible individuals, release of mediators and an increase in blood coagulability. A literature survey has provided some support for the hypothesis of possible association between occupational exposure to dust and increased risk of ischaemic heart disease [98-100]. For example, coal miners showed manifestations of pneumoconiosis and increased incidence of ischaemic heart disease. There were also increased levels of fibrinogen in the blood of coal miners with pneumoconiosis, and fibrinogen is a risk factor for ischaemic heart disease. A hypothesis has been put forward that long-term inhalation of particles retained in the lung induces an inflammation which is accompanied by an increase of plasma fibrinogen, leading to elevated risk for blood clotting and ischaemic heart disease [100].

In a recent study combining measurement of air pollution exposure with personal meters and of haematological markers in collected blood, it was found that there was a relationship between exposure to particulate matter, measured as PM10, and changes in haemoglobin concentration, haematocrit (packed cell volume) and red blood cell count [101]. There were concomitant decreases in platelet number and fibrinogen levels. By also measuring plasma albumin, the authors concluded that the decrease in haemoglobin was caused by increased peripheral sequestration of red blood cells, rather that generalized haemodilution. The study supports particulate air pollution, or a very closely associated confounding factor, having the potential to affect important cardiovascular phenomena. Studies of acute episodes of increased air pollution have documented effects on plasma viscosity [102], and acute exposure to DE has effects on inflammatory cells in the blood [28]. In a time series panel study of particulate air pollution, there was an association between particle levels and pulse, but not with oxygen saturation [103]. There was a time lag between exposure and the effect on pulse that the authors interpreted as an indication of lung inflammation with consequent release of mediators and cytokines being the primary event. Some recent studies in the elderly [104-106] have implied an association between increased particulate matter (PM2.5) in ambient air pollution and decreased heart rate variability, suggesting a possible contribution to increased cardiovascular mortality and decreased autonomic control.

The studies of the direct influence of DE on various cardiovascular responses, however, remain very few. Pretreatment of human serum with DEP extracts (500 $2,500 \mu \mathrm{g} \cdot \mathrm{mL}^{-1}$ ) gave a dose-dependent reduction in complement haemolytic activity of up to $20 \%$ [107], and activation of the alternative complement pathway. A direct toxic action of DEPs was examined in a model of isolated atria from guinea pigs [108]. DEPs in lower doses $\left(10-500 \mu \mathrm{g} \cdot \mathrm{mL}^{-1}\right)$ induced a transient but dosedependent increase in contractile force. DEPs in doses $>500 \mu \mathrm{g} \cdot \mathrm{mL}^{-1}$, only decreased contractile force and induced cardiac arrest. It was concluded that cardiac toxicity contributes to the lung oedema that is known to be one prominent cause of death in DEPs exposed animals. It appears unlikely, however, that inhalation of DEPs by humans could produce the concentrations employed in these particular experiments. The experiments indicating effects of DE on the NO system and oxygen radical formation have been discussed above. All in all, the possible mechanisms involved in the alleged role of $\mathrm{DE}$ on various cardiovascular events remain unknown.

\section{Discussion}

The epidemiological support for particle effects on asthma and respiratory health is very evident. The experimental studies of DEPs include in vitro models, animal in vivo models, studies of healthy humans and occasional observations in patients. Respiratory, immunological and systemic effects have indeed been documented. The main effects on the respiratory system are summarized in table 1.

The acute effects include irritation of the nose and eye, lung function changes, airway inflammation, headache, fatigue and nausea. In addition to symptoms, exposure studies in healthy humans have documented a number of profound inflammatory changes in the airways, notably, before changes in pulmonary function can be detected. It is likely that such effects may be even more detrimental in asthmatics and other subjects with compromised pulmonary function.

Chronic exposure to DE induces cough, sputum production and lung function decrements. Pathological and histological findings in the lung after DEPs exposure have mostly been studied in rats and include increases in lung weight, increased numbers of particles in the lung and an increased burden of soot, associated with alveolar infiltration of macrophages, macrophage aggregation, chronic inflammatory responses, proliferation and hyperplasia of alveolar epithelium and type 2 cells, thickening of alveolar septa and wall fibrosis.

Due to the complexity of DE, it is likely that some effects are caused by the gaseous components whereas other effects relate to the particle content. The suggested mechanisms of detrimental actions of particulate matter include oxidative stress and actions of particulate matter content such as metals, hydrocarbons, acids and carbon core. The ultrafine particles are currently suspected of being the most aggressive particulate component of DE. Comparison of DEPs and carbon black in animal inhalation studies show that both induce a reduction in lung function and accumulation of macrophages, suggesting that the toxic effect of DEPs is, in part, coupled to the carbon core. However, much more work is needed to pinpoint the relative role of different components of DE, as well as the interaction between the different components, and other environmental factors.

There are several observations that support the hypothesis that DE is one important factor contributing to the allergy pandemic. For example, DEPs introduced by different routes, intraperitoneally, intranasally or intratracheally, may act as adjuvant to allergen and 
Table 1. - Some effects of diesel emission with relevance to the respiratory system

\begin{tabular}{|c|c|c|}
\hline System & Effects & Reference \\
\hline Human volunteers & $\uparrow$ airway resistance and inflammation & {$[21,26]$} \\
\hline $\begin{array}{l}\text { Exposure chamber } \\
\text { challenge }\end{array}$ & $\begin{array}{l}\uparrow \text { neutrophils in BAL and sputum } \\
\text { mast cells in BAL, } \uparrow \text { mast cells in airway mucosa } \\
\uparrow \text { in ICAM-1, VCAM-1 } \\
\uparrow \text { in IL- } 8 \text { in airway epithelium } \\
\uparrow \text { in IL-6 in sputum }\end{array}$ & $\begin{array}{l}{[26,28,31,32]} \\
{[26,28]} \\
{[28,29,30]} \\
{[31]} \\
{[32]}\end{array}$ \\
\hline Humans & $\uparrow$ in local IgE & {$[33,37]$} \\
\hline Nasal provocations & $\begin{array}{l}\uparrow \text { in IgE secreting cells } \\
\uparrow \uparrow \text { spec IgE (DEP + antigen) } \rightarrow \text { allergic sensitization } \\
\uparrow \text { in IL-4, IL-5, IL-6, IL-10 }\end{array}$ & {$[33]$} \\
\hline $\begin{array}{l}\text { Rat } \\
\text { Chronic exposure }\end{array}$ & $\begin{array}{l}\text { Increased lung weight, chronic inflammation with increased } \\
\text { number of inflammatory cells, chronic degenerative changes }\end{array}$ & {$[41-43,51,55,57]$} \\
\hline & $\begin{array}{l}\text { Bronchiolo-alveolar hyperplasia } \\
\text { Prolongation of clearance }\end{array}$ & $\begin{array}{l}{[42,55,57]} \\
{[43,51]}\end{array}$ \\
\hline $\begin{array}{l}\text { Cat } \\
\text { Chronic exposure }\end{array}$ & $\begin{array}{l}\text { Pattern of restrictive lung disease, inflammatory reactions, } \\
\text { bronchiolo metaplasia }\end{array}$ & {$[48,49]$} \\
\hline $\begin{array}{l}\text { Mice } \\
\text { Acute high exposure }\end{array}$ & $\begin{array}{l}\text { Severe lung injury, high mortality, cause of death: pulmonary } \\
\text { oedema }\end{array}$ & {$[50]$} \\
\hline $\begin{array}{l}\text { Mice } \\
\text { Chronic exposure }\end{array}$ & $\begin{array}{l}\text { Airway inflammation with increased number of inflammatory } \\
\text { cells }\end{array}$ & {$[62,63,65,94]$} \\
\hline & $\begin{array}{l}\uparrow \text { goblet cells } \\
\uparrow \text { respiratory resistance }\end{array}$ & $\begin{array}{l}{[65,70]} \\
{[70]}\end{array}$ \\
\hline Mice & $\uparrow \mathrm{IgE}$ levels & {$[58,59]$} \\
\hline DEP + allergen & $\uparrow$ spec IgE levels & {$[58,59,65,70]$} \\
\hline Exposure & $\begin{array}{l}\uparrow \text { spec IgG } \text { I levels }_{1} \\
\text { IL-2, IL-4, IL-5 } \\
\text { GM-CSF }\end{array}$ & $\begin{array}{l}{[62,63,70]} \\
{[62,70]} \\
{[62]}\end{array}$ \\
\hline Human nasal epithelial cells & $\uparrow$ adhesion and degranulation of eosinophils & [78] \\
\hline$(\mathrm{HNEC})$ & $\uparrow$ IL-1 $\beta$, IL-6, IL-8 & {$[79,80]$} \\
\hline In vitro exposure & $\begin{array}{l}\uparrow \text { GM-CSF } \\
\uparrow \text { adhesion molecules }\end{array}$ & $\begin{array}{l}{[79,80]} \\
{[80]}\end{array}$ \\
\hline Human bronchial cell culture & $\uparrow$ IL-1 $\beta$, IL-6, IL-8 & {$[79,80]$} \\
\hline In vitro exposure & $\begin{array}{l}\uparrow \mathrm{GM}-\mathrm{CSF} \\
\uparrow \text { adhesion molecules }\end{array}$ & $\begin{array}{l}{[79,80,85]} \\
{[80,85]}\end{array}$ \\
\hline Human bronchial epethelial cell & IL-6, IL-8 & {$[84,87]$} \\
\hline (HBEC) & $\uparrow$ IL-8 mRNA & {$[88]$} \\
\hline In vitro exposure & $\begin{array}{l}\uparrow \mathrm{GM}-\mathrm{CSF} \\
\uparrow \mathrm{sICAM}-1\end{array}$ & {$[84]$} \\
\hline $\begin{array}{l}\text { Human B-cell line } \\
\text { In vitro exposure }\end{array}$ & $\uparrow \mathrm{IgE}$ production & {$[82]$} \\
\hline Human peripheral blood & $\uparrow$ IL-8 & [83] \\
\hline mononuclear cells (PBMC) & $\uparrow \mathrm{RANTES}$ & {$[83]$} \\
\hline In vitro exposure & $\downarrow$ MCP-1 secretion & {$[83]$} \\
\hline Rat alveolar macrophages & IL-1 & [90] \\
\hline In vitro exposure & IL- 1, TNF- $\alpha$ - stimulated by endotoxin & {$[90]$} \\
\hline
\end{tabular}

BAL: bronchoalveolar lavage; DEP: diesel exhaust particles; GM-CSF: granulocyte macrophage colony stimulating factor; ICAM-1: intracellular cell adhesion molecule; IL: interleukin; MCP-1: monocyte chemotactic peptide 1; MRNA: messenger ribonucleic acid; RANTES: regulated on activation normal T-cell expressed and secreted; ICAM-1: soluble intracelluler adhesion molecule; TNF- $\alpha$ : tumour necrosis factor alpha; VCAM-1: vascular cell adhesion molecule-1; $\uparrow:$ increase; $\downarrow$ : decrease.

hence increase the sensitization response. This has been observed both in human and animal studies. IgE production in response to allergen has been shown to be enhanced by DE. DEPs affect human B-cells and may enhance IgE production by several mechanisms. In addition, DEPs show effects on the allergic response that involve inflammatory cells in the respiratory mucosa, such as T cells, mast cells and epithelial cells, and also on local production of various pro-inflammatory cytokines. Another possible mechanism of action of DEPs on allergic responses is to act as a carrier of pollen allergens, allowing enhanced deposition of pollen in the lower airways. Allergens bound to DEPs may trigger asthma attacks and DEP-binding may facilitate penetration of allergen through the airway mucosa.

It is often believed that atopic children are a specially sensitive group, but the few animal studies that have been carried out have not supported the hypothesis that the developing lung [51] or lungs with induced emphysema [53] are more prone to lung injury due to particulate matter. On the basis of published data, there is no single mechanism of action, that can explain the various public health effects of particulate air pollution shown in epidemiological studies. One major shortcoming of many experimental studies relates to their inability to establish whether or not the exposures 
used for the studies are relevant to the background or peak exposures which may occur in real life, acutely or chronically. In addition, theoretically, both acute exposure to high levels of diesel exhaust particles and chronic exposure to low levels may impair respiratory functions and have various other detrimental effects, but the mechanisms may be different. Such a situation exists in the case of a classical trigger of asthma such as allergen: acute exposure to high allergen doses produces effects that differ from those caused by repeated low dose exposure [109-111]. As reviewed, some of the studies of chronic exposure of rats to diesel exhaust particles (vide supra) also highlight such differences between high and low dose exposures. It is therefore imperative to further assess acute and chronic effects of diesel exhaust in mechanistic studies with careful consideration of exposure levels. Whenever possible and ethically justified, such studies should be performed in humans, but animal and cell culture models that are sufficiently predictive and sensitive, may also provide important information on these matters.

\section{References}

1. Salvi $\mathrm{S}$, Frew A, Holgate $\mathrm{S}$. Is diesel exhaust a cause for increasing allergies? Clin Exp Allergy 1999; 29: 4-8.

2. Salvi S, Holgate S. Mechanisms of particulate matter toxicity. Clin Exp Allergy 1999; 29: 1187-1194.

3. United Nations Environment Program. Air pollution in the worlds megacities. Environment 1994; 36: 5-37.

4. Department of Health. Particle dosimetry. Nonbiological particles and health. COMPEAP (Committee on the Medical Effects of Air Pollutants). 1995; 29-42.

5. Nauss KM, Busby WF Jr, Cohen AJ, et al. Critical issues in assessing the carcinogenicity of diesel exhaust: A synthesis of current knowledge. In: Health Effects Institutés Diesel working group, eds. Diesel exhaust A critical analysis of emission, exposure and health effects. Cambridge, MA., Health Effects Institute, 1995; pp. 13-18.

6. Zweidinger RL, Garland $\mathrm{D}$, Oliver $\mathrm{CN}$, et al. The determination of carbonyl content in oxidatively modified proteins. In: Packer L, Glazier $\mathrm{AN}$, eds. London, Academic Press, 1990; 464-477.

7. Brain JD, Valberg PA. Deposition of aerosol in the respiratory tract. Am Rev Respir Dis 1979; 120: 13251373.

8. Chow JC. Measurement methods to determine compliance with ambient air quality standards for suspended particles. J Air Waste Manag Assoc 1995; 45: 320-382.

9. Anderson M, Svartengren M, Philipson K, Camner P. Regional human lung deposition studied by repeated investigations. J Aerosol Sci 1994; 25: 567-581.

10. Scheepers PT, Bos RP. Combustion of diesel fuel from a toxicological perspective. I. Origin of incomplete combustion products. Int Arch Occup Environ Health 1992; 64: 149-161.

11. Cammer P, Perschagen G, Ahlborg U, Ljungvist S, Victorin K. Health effects of diesel exhaust emissions. (1988) Stockholm, Nordic Council of Ministers.

12. Yoshino S, Sagai M. Enhancement of collageninduced arthritis in mice by diesel exhaust particles. J Pharmacol Exp Ther 1999; 290: 524-529.
13. Schwartz J, Dockery DW, Neas LM. Is daily mortality associated specifically with fine particles? J Air Waste Manag Assoc 1996; 46: 927-939.

14. Seaton A, MacNee W, Donaldson K, Godden D. Particulate air pollution and acute health effects. Lancet 1995; 345: 176-178.

15. D'Amato G, Liccardi G, D'Amato M. Environment and development of respiratory allergy: I. Outdoors. Monaldi Arch Chest Dis 1998; 49: 406-411.

16. Boezen HM, van der Zee SC, Postma DS, et al. Effect of ambient air pollution on upper and lower respiratory symptoms and peak expiratory flow in children. Lancet 1999; 353: 874-878.

17. Hobbs $\mathrm{CH}$, Mauderly JL. Risk assessment for diesel exhaust and ozone: The data from people and animals. Clin Toxicol 1991; 29: 375-384.

18. Rusznak C, Devalia JL, Davies RJ. The impact of pollution on allergic disease. Allergy 1994; 49: 21-27.

19. US Environmental Protection Agency. Toxicological studies of particulate matter. 1996. Triangle Park, NC, USA. US Environmental Protection Agency. Air Quality criteria for particulate matter; vol II, chapter 11, pp. 1-231.

20. Morgan WKC, Reger RB, Tucker DM. Health effects of diesel emissions. Ann Occup Hyg 1997; 41: 643-658.

21. Rudell B, Ledin M-C, Hammarström U, Stjernberg N, Lundbäck B, Sandström T. Effects on symptoms and lung function in humans experimentally exposed to diesel exhaust. Occup Environment Med 1996; 53: 658662.

22. Scheepers PTJ, Bos RP. Combustion of diesel fuel from a toxicological perspective. II. Toxicity. Int Arch Occup Environ Health 1992; 64: 163-177.

23. Kim $\mathrm{CS}, \mathrm{Hu}$ SC. Regional deposition of inhaled particles in human lungs: comparison between men and women. Am J Physiol 1998; 84: 1834-1844.

24. Wade JF, Newman LS. Diesel asthma. Reactive airways disease following overexposure to locomotive exhaust. JOM 1993; 35: 149-154.

25. Rudell B, Sandström T, Hammarström U, Ledin M-L, Hörstedt P, Stjernberg N. Evaluation of an exposure setup for studying effects of diesel exhaust in humans. Int Arch Occup Environ Health 1994; 66: 77-83.

26. Rudell B, Sandstrom T, Stjernberg N, KolmodinHedman B. Controlled diesel exhaust exposure in an exposure chamber: Pulmonary effects investigated with bronchoalveolar lavage. J Aerosol Sci 1990; 21: 411-414.

27. Rudell B, Wass U, Hörstedt P, et al. Efficiency of automotive cabin air filters to reduce acute health effects of diesel exhaust in human subjects. Occup Environ Med 1999; 56: 222-231.

28. Salvi S, Blomberg A, Rudell B, et al. Acute inflammatory responses in the airways and peripheral blood after short-term exposure to diesel exhaust in healthy human volunteers. Am J Respir Crit Care Med 1999; 159: 702-709.

29. Montefort S, Lai CK, Kapahi P, et al. Circulating adhesion molecules in asthma. Am J Respir Crit Care Med 1994; 149: 1149-1152.

30. Montefort S, Gratziou C, Goulding D, et al. Bronchial biopsy evidence for leukocyte infiltration and upregulation of leukocyte-endothelial cell adhesion molecules 6 hours after local allergen challenge of sensitized asthmatic airways. J Clin Invest 1994; 93 : 1411-1421.

31. Salvi SS, Nordenhall C, Blomberg A, et al. Acute short 
term exposure to diesel exhaust increases IL- 8 and GRO- $\alpha$ production in healthy human airways. $\mathrm{Am}$ J Respir Crit Care Med 2000; 161: 550-557.

32. Nordenhäll C, Pourazar J, Blomberg A, Levin J-O, Sandstrom T, Ädelroth E. Airway inflammation following exposure to diesel exhaust: A study of time kinetics using induced sputum. Eur Respir $J$ 2000; 15: 1046-1051.

33. Diaz-Sanchez D, Dotson AR, Takenaka H, Saxon A. Diesel exhaust particles induce local IgE production in vivo and alter the pattern of messenger RNA isoforms. J Clin Invest 1994; 94: 1417-1425.

34. Diaz-Sanchez D. The role of diesel exhaust particles and their associated polyaromatic hydrocarbons in the induction of allergic airway disease. Allergy 1997; 52: 52-56.

35. Prescott SL, Macaubas C, Smallacombe T, Holt BJ, Sly PD, Holt PG. Development of allergen-specific Tcell memory in atopic and normal children. Lancet 1999; 353: 196-200.

36. Diaz-Sanchez D, Tsien A, Fleming J, Saxon A. Combined diesel exhaust particulate and ragweed allergen challenge markedly enhances human in vivo nasal ragweed-specific IgE and skews cytokine production to a $\mathrm{T}$ helper cell 2-type pattern. J Immunol 1997; 158: 2406-2413.

37. Fujieda S, Diaz-Sanchez D, Saxon A. Combined nasal challenge with diesel exhaust particles and allergen induces in vivo IgE isotype switching. Am J Respir Cell Mol Biol 1998; 19: 507-512.

38. Diaz-Sanchez D, Tsien A, Casillas A, Dotson AR, Saxon A. Enhanced nasal cytokine production in human beings after in vivo challenge with diesel exhaust particles. J Allergy Clin Immunol 1996; 98: 114-123.

39. Sandstrom T, Blomberg A, Helleday R, Rudell B. Air pollution allergy interaction: experiences from animal studies. Eur Respir Rev 1998; 8: 168-174.

40. Olander L. Luftföroreningar i fordon (Contaminants inside cars - concentrations and measures). Arbetslivsinstitutet (The Swedish National Institute for Working Life) 1996. Stockholm.

41. Kato A, Kyono H, Kuwabara N. Electron-microscopic observations on rat lungs after long term inhalation of diesel emissions -- non-neoplastic lesions. Japanese J Thoracic Dis 1992; 30: 238-247.

42. Mohr U, Takenaka S, Dungworth DL. Morphological effects of inhaled diesel engine exhaust on lungs of rats: Comparison with effects of coal oven flue gas mixed with pyrolyzed pitch. In: Ishinishi N, Koizumi A, McClellan RO, Stöber W, Eds. Carcinogenic and mutagenic effects of diesel engine exhaust. Amsterdam, Elsevier Science Publishers B.V., 1986; 459-470.

43. Wolff RK, Henderson RF, Snipes MB. Alterations in particle accumulation and clearance in lungs of rats chronically exposed to diesel exhaust. Fundam Appl Toxicol 1987; 9: 154-166.

44. Pritchard JN. Dust overloading causes impairment of pulmonary clearance: Evidence from rats and humans. Exp Pathol 1989; 37: 39-42.

45. Strom KA, Garg BD, Johnson JT, D'Arcy JB, Smiler $\mathrm{KL}$. Inhaled particle retention in rats receiving low exposures of diesel exhaust. J Toxicol Environ Health 1990; 29: 377-398.

46. Yu CP, Yoon KJ. Retention modeling of diesel exhaust particles in rats and humans. Research Report Health Effects Institute 1991; 40: 1-24.

47. Falk R, Philipson K, Svartengren M, et al. Assessment of long-term bronchiolar clearance of particles from measurements of lung retention and theoretical estimates of regional deposition. Exp Lung Res 1999; 25: 495-516.

48. Moorman WJ, Clark JC, Pepelko WE, Mattox J. Pulmonary function responses in cats following longterm exposure to diesel exhaust. J Appl Toxicol 1985; 5: 301-305.

49. Hyde DM, Plopper CG, Weir AJ. Peribronchial fibrosis in lungs of cats chronically exposed to diesel exhaust. Lab Invest 1985; 52: 195-206.

50. Sagai M, Saito H, Ichinose T, Kodama M, Mori Y. Biological effects of diesel exhaust particles. I. In vitro production of superoxide and in vivo toxicity in mouse. Free Rad Biol Med 1993; 14: 37-47.

51. Mauderly JL, Bice DE, Carpenter RL, et al. Effects of inhaled nitrogen dioxide and diesel exhaust on developing lung. Research Report - Health Effects Institute 1987; 8: 3-37.

52. Motley HL. Environmental air pollution effect on pulmonary function. Aerospace Med 1971; October: $1108-1110$.

53. Mauderly JL, Bice DE, Cheng YS, et al. Influence of preexisting pulmonary emphysema on susceptibility of rats to inhaled diesel exhaust. Am Rev Respir Dis 1990; 141: 1333-1341.

54. Mauderly JL, Bice DE, Cheng YS, et al. Influence of experimental pulmonary emphysema on the toxicological effects from inhaled nitrogen dioxide and diesel exhaust. Research Report - Health Effects Institute 1989; 30: 1-47.

55. Nikula KJ, Avila KJ, Griffith WC, Mauderly JL. Sites of particle retention and lung tissue responses to chronically inhaled diesel exhaust and coal dust in rats and Cynomolgus monkeys. Environ Health Perspect 1997; 105: 1231-1234.

56. Nikula KJ, Avila KJ, Griffith WC, Mauderly JL. Lung tissue responses and sites of particle retention differ between rats and Cynomolgus monkeys exposed chronically to diesel exhaust and coal dust. Fundam Appl Toxicol 1997; 37: 37-53.

57. Bice DE, Mauderly JL, Jones RK, McClellan RO. Effects of inhaled diesel exhaust on immune responses after lung immunization. Fundam Appl Toxicol 1985; 5: 1075-1086.

58. Muranaka M, Suzuki S, Koizumi K, et al. Adjuvant activity of diesel-exhaust particulates for the production of $\mathrm{IgE}$ antibody in mice. $J$ Allergy Clin Immunol 1986; 77: 616-623.

59. Maejima K, Tamura K, Taniguchi Y, Nagase S, Tanaka H. Comparison of effects of various fine particles on IgE antibody production in mice inhaling Japanese Cedar pollen allergens. J Toxicol Environ Health 1997; 52: 231-248.

60. Nilsen A, Hagemann R, Eide I. The adjuvant activity of diesel exhaust particles and carbon black on systemic IgE production to ovalbumin in mice after intranasal instillation. Toxicology 1997; 124: 225-232.

61. Lovik M, Hogseth A-K, Gaarder PI, Hagemann R, Eide I. Diesel exhaust particles and carbon black have adjuvant activity on the local lymph node response and systemic IgE production to ovalbumin. Toxicology 1997; 121: 165-178.

62. Takano H, Yoshikawa T, Ichinose T, Miyabara Y, Imaoka K, Sagai M. Diesel exhaust particles enhance antigen-induced airway inflammation and local 
cytokine expression in mice. Am $J$ Respir Crit Care Med 1997; 156: 36-42.

63. Ichinose T, Takano H, Miyabara Y, Yanagisawa R, Sagai M. Murine strain differences in allergic airway inflammation and immunoglobulin production by a combination of antigen and diesel exhaust particles. Toxicology 1997; 122: 183-192.

64. Miyabara Y, Ichinose T, Takano H, Lim HB, Sagai M. Effects of diesel exhaust on allergic airway inflammation in mice. J Allergy Clin Immunol 1998; 102: 805-812.

65. Fujimaki $\mathrm{H}$, Nohara $\mathrm{O}$, Ichinose $\mathrm{T}$, Watanabe $\mathrm{N}$, Saito S. IL-4 production in mediastinal lymph node cells in mice intratracheally instilled with diesel exhaust particulates and antigen. Toxicology 1994; 92: 261-268.

66. Takano H, Ichinose T, Miyabara Y, Yoshikawa T, Sagai M. Diesel exhaust particles enhance airway responsiveness following allergen exposure in mice. Immunopharm Immunotoxicol 1998; 20: 329-336.

67. Takano H, Ichinose T, Miyabara $\mathrm{Y}$, et al. Inhalation of diesel exhaust enhances allergen-related eosinophil recruitment and airway hyperresponsiveness in mice. Toxicol Appl Pharmacol 1998; 150: 328-337.

68. Takafuji S, Suzuki S, Koizumi K, et al. Enhancing effect of suspended particulate matter on the IgE antibody production in mice. Int Arch Allergy Appl Immunol 1989; 90: 1-7.

69. Miyabara Y, Ichinose T, Takano H, Sagai M. Diesel exhaust inhalation enhances airway hyperresponsiveness in mice. Int Arch Allergy Immunol 1998; 116: 124 131.

70. Miyabara Y, Takano H, Ichinose T, Lim H-B, Sagai M. Diesel exhaust enhances allergic airway inflammation and hyperresponsiveness in mice. Am J Respir Crit Care Med 1998; 157: 1138-1144.

71. Kobayashi $\mathrm{T}$, Ikeue $\mathrm{T}$, Ito $\mathrm{K}$, et al. Short-term exposure to diesel exhaust induces nasal mucosal hyperresponsiveness to histamine in guinea pigs. Fundam Appl Toxicol 1997; 38: 166-172.

72. Hiruma K, Terada N, Hanazawa T, et al. Effect of diesel exhaust on guinea pig nasal mucosa. Ann Otol Rhinol Laryngol 1999; 108: 582-588.

73. Gorski P, Tarkowski M, et al. Non specific environmental factors and asthma development. Polish J Occup Med Environ Health 1992; 5: 227-236.

74. Glovsky MM, Miguel AG, Cass GR. Particulate air pollution: Possible relevance in asthma. Allergy Asthma Proc 1997; 18: 163-166.

75. Knox RB, Suphioglu C, Taylor P, et al. Major grass pollen allergen Lol p 1 binds to diesel exhaust particles: implications for asthma and air pollution. Clin Exp Allergy 1997; 27: 246-251.

76. Ormstad H, Johansen BV, Gaarder PI. Airborne house dust particles and diesel exhaust particles as allergen carriers. Clin Exp Allergy 1998; 28: 702-708.

77. Henricsson S, Westerholm R, Nilsson S, Berggren B. Chemical characterisation of extractable compounds found in the coating of birch (Betula) pollen. Grana 1996; 35: 179-184.

78. Terada N, Maesako K, Hiruma K. Diesel exhaust particulates enhance eosinophil adhesion to nasal epithelial cells and cause degranulation. Int Arch Allergy Appl Immunol 1997; 114: 167-174.

79. Boland S, Baeza-Squiban A, Fournier T, et al. Diesel exhaust particles are taken up by human airway epithelial cells in vitro and alter cytokine production. Am J Physiol 1999; 276: L604-L613.

80. Devalia JL, Bayram H, Rusznak C, et al. Mechanisms of pollution-induced airway disease: In vitro studies in the upper and lower airways. Allergy 1997; 52: 4551 .

81. Takenaka H, Zhang K, Diaz-Sanchez D, Tsien A, Saxon A. Enhanced human IgE production results from exposure to the aromatic hydrocarbons from diesel exhaust: Direct effects on B-cell IgE production. J Allergy Clin Immunol 1995; 95: 103-115.

82. Tsien A, Diaz-Sanchez D, Ma J, Saxon A. The organic component of diesel exhaust particles and phenanthrene, a major polyaromatic hydrocarbon constituent, enhances $\mathrm{IgE}$ production by $\mathrm{IgE}$-secreting EBV-transformed human B cells in vitro. Toxicol Appl Pharmacol 1997; 142: 256-263.

83. Fahy O, Tsicopoulos A, Hammad H, Pestel J, Tonnel AB, Wallaert B. Effects of diesel organic extracts on chemokine production by peripheral blood mononuclear cells. J Allergy Clin Immunol 1999; 103: 11151124.

84. Bayram H, Devalia JL, Sapsford RJ, et al. The effect of diesel exhaust particles on cell function and release of inflammatory mediators from human bronchial epithelial cells in vitro. Am J Respir Cell Mol Biol 1998; 18: 441-448.

85. Bayram H, Devalia JL, Khair OA, et al. Comparison of ciliary activity and inflammatory mediator release from bronchial epithelial cells of nonatopic nonasthmatic subjects and atopic asthmatic patients and the effect of diesel exhaust particles in vitro. J Allergy Clin Immunol 1998; 102: 771-782.

86. Ohtoshi T, Takizawa H, Okazaki H, et al. Diesel exhaust particles stimulate human airway epithelial cells to produce cytokines relevant to airway inflammation in vitro. J Allergy Clin Immunol 1998; 101: 778785 .

87. Steerenberg PA, Zonnenberg JAJ, Dormans JAMA, et al. Diesel exhaust particles induced release of interleukin 6 and 8 by (primed) human bronchial epithelial cells (BEAS 2B) in vitro. Exp Lung Res 1998; 24: 85-100.

88. Takizawa $\mathrm{H}$, Ohtoshi $\mathrm{T}$, Kawasaki $\mathrm{S}$, et al. Diesel exhaust particles induce NF-kappa $\mathrm{B}$ activation in human bronchial epithelial cells in vitro: importance in cytokine transcription. J Immunol 1999; 162: 47054711.

89. Terada N, Hamano N, Maesako KI, et al. Diesel exhaust particulates upregulate histamine receptor mRNA and increase histamine-induced IL-8 and GM-CSF production in nasal epithelial cells and endothelial cells. Clin Exp Allergy 1999; 29: 52-59.

90. Yang H-M, Ma JYC, Castranova V, Ma JKH, et al. Effects of diesel exhaust particles on the release of interleukin-1 and tumor necrosis factor-alpha from rat alveolar macrophages. Exp Lung Res 1997; 23: 269-284.

91. Hirafuji M, Sakakibara M, Endo T, et al. Biological effects of diesel exhaust particles (DEP) on tissues and cells isolated from respiratory tracts of guinea pigs. Res Comm Mol Pathol Pharmacol 1995; 90: 221233.

92. Vogl G, Elstner EF. Diesel soot particles catalyze the production of oxy-radicals. Toxicol Lett 1989; 47: 1723.

93. Bingisser RM, Tilbrook PA, Holt PG, Kees UR. 
Macrophage-derived nitric oxide regulates T cell activation via reversible disruption of the Jak3/STAT5 signaling pathway. J Immunol 1998; 160: 5729-5734.

94. Sagai M, Ichinose T. Role of nitric oxide in asthmalike symptoms induced by diesel exhaust particles in mice. Japanese J Thoracic Dis 1995; 33: 212-217.

95. Muto E, Hayashi T, Yamada K, Esaki T, Sagai M, Iguchi A. Endothelial-constitutive nitric oxide synthase exists in airways and diesel exhaust particles inhibit the effect of nitric oxide. Life Sci 1996; 59: 1563-1570.

96. Dockery DW, Pope CA. Acute respiratory effects of particulate air pollution. Ann Rev Publ Health 1994; 15: 107-132.

97. Schwartz J. Air pollution and daily mortality: a review and meta analysis. Environ Res 1994; 64: 36-52.

98. Sjögren B. Occupational exposure to dust: Inflammation and ischaemic heart disease. Occup Environment Med 1997; 54: 466-469.

99. Sjögren B. Mortality of Dutch coal miners in relation to pneumoconiosis, chronic obstructive pulmonary disease, and lung function. Occup Environment Med 1998; 55: 503-503.

100. Sjögren B. A possible connection between furnace dust exposure, plasma fibrinogen levels and cardiovascular disease. Scand J Work Environ Health 1998; 24: 236-237.

101. Seaton A, Soutar A, Crawford V, Stout R, et al. Particulate air pollution and the blood. Thorax 1999; 54: 1027-1032.

102. Peters A, Doring A, Wichmann HE, Koenig W. Increased plasma viscosity during the 1985 air pollution episode: a link to mortality? Lancet 1997; 349: 15821587.
103. Pope CA, III, Dockery DW, Kanner RE, Villegas GM, Schwartz J. Oxygen saturation, pulse rate, and particulate air pollution. Am J Respir Crit Care Med 1999; 159: 365-372.

104. Gold DR, Litonjua A, Schwartz J, et al. Ambient pollution and heart rate variability. Circulation 2000; 101: 1267-1273.

105. Liao D, Creason J, Shy C, Williams R, Watts R, Zweidinger R. Daily variation of particulate air pollution and poor cardiac autonomic control in the elderly. Environ Health Perspect 1999; 107: 521-525.

106. Pope III CA, Verrier RL, Lovett EG, et al. Heart rate variability associated with particulate air pollution. Am Heart J 1999; 138: 890-899.

107. Kanemitsu H, Nagasawa S, Sagai M, Mori Y. Complement activation by diesel exhaust particles (DEP). Biol Pharm Bull 1998; 21: 129-132.

108. Sakakibara M, Minami M, Endo T, et al. Biological effects of diesel exhaust particles (DEP) on isolated cardiac muscle of guinea pigs. Res Comm Mol Pathol Pharmacol 1994; 86: 99-110.

109. Ihre E, Zetterstrom O. Increase in non-specific bronchial responsiveness after repeated inhalation of low doses of allergen. Clin Exp Allergy 1993; 23: 298-305.

110. Sulakvelidze I, Inman MD, Rerecich T, O'Byrne PM. Increases in airway eosinophils and interleukin-5 with minimal bronchoconstriction during repeated lowdose allergen challenge in atopic asthmatics. Eur Respir J 1998; 11: 821-827.

111. Arshad SH, Hamilton RG, Adkinson NF, Jr. Repeated aerosol exposure to small doses of allergen. A model for chronic allergic asthma. Am J Respir Crit Care Med 1998; 157: 1900-1906. 